DOI https://doi.org/10.36059/978-966-397-161-2/1-25

\title{
DEVELOPMENT OF PERSONAL CREATIVE POTENTIAL IN ONTOGENY
}

\section{Valentyna Afanasenko}

\section{INTRODUCTION}

Human vitality in a network society, relevance to non-linear innovative and unpredictable processes of life that include variety of changes and scenarios are based on a unique resource - the personal creative potential. It combines uniqueness and universal capacity for development that leads to quality transformation, new activity and updating. Creativity as an activity implies that the old and the new become action forms. However, creativity is not just a new activity but a qualitatively new performance based on the reorganization of activity.

If the activity is focused on its intensity without demonstrating meaningful signs of transformation and does not lead to the emergence of a qualitatively new product, it is a way of the world development in the form of human activity. Therefore, creativity as a human activity involves capacity for development due to which qualitatively new results appear. Its value is not only in the absolute newness emerging in the process of human activity, but mainly in discovering something new for the self and in the self regardless of its novelty to others. Moreover, the concept "new" is quite ambiguous.

The problem of the creative personality in the diachronic dimension has a priority status in the system of knowledge about the human. Theoretical praxeological and research of its development were contributed by F. Barron, M. Berdiaev, A. Bergson, J. Guilford, V. Gordon, A. Maslow, K. Rogers, C. Taylor, R. Torrens, V. Frankl, S. Freud and others.

The development process of a creative personality is analyzed as a multidisciplinary problem in various aspects: the correlation of intellectual abilities, creative qualities and thinking of the individual 
(V. Andreev, I. Kon, T. Kudriavtsev, V. Moliako, E. Moren, G. Lindsey, J. Piaget, B. Teplov, K. Hall, etc.),

Currently the phenomenon of "creative potential" is relevant and used in various spheres of human existence as the basic concept in the anthropocentric paradigm. However, it has latent nature and nonlinear development. Therefore, scientific and psychological analysis of ego development is valuable in this sense as it is the basis for presenting the features of the creative potential development.

\section{Concepts of personality development in scientific researches of the XX century}

The concept of development as a linear progress has changed under the influence of the of phenomenology and existentialism ideas in the 20th century. "Here-and-now" principle integrating the past, present and future becomes the initial one; it brings together various structures of the constantly evolving world and the person capable of self-development.

Experiencing different history states is typical for the nonclassical philosophy paradigm. These states follow each other and simultaneous stay in all of them constitutes the wholeness of being in three temporal dimensions.

M. Heidegger analysed it through the past and the future in the present ${ }^{1}$. Such understanding of time in its development involves the formation of the universum wholeness in the sequence of its events, integrating all its moments and history states.

In postmodern philosophy, different interpretations of development exist. Thus, in the concept by H. Shchedrovytskyi it is defined through self development, a qualitative change of the object, substance (nature, activity, mental activity). In his methodology, development is interpreted as the change of the sequential history states of the system object ${ }^{2}$. Each successive state is genetically linked

${ }^{1}$ Heidegger, M. (2003) Bytie i vremya [Being and time]. Kharkov, Ukraine: Folio. (in Russian)

2 Shchedrovitskyi, H. (1995) Izbrannye Trudy [Selected works]. Moscow, Russia: Shkola kulturnoi politiki. (in Russian). 
to the previous one in its structure. Development is the transition from the structure of one quality to the structure of another. It is emphasized that the object is developed not partly but its parts are formed depending on the change of the whole object. According to the authors, seeing "qualitative", genetically conditioned changes in the structure of the whole object can only be based on the system of standards that allows to estimate the development and adequate stepby-step marking. Development is interpreted not as a natural time indicator, but as the vital activity of the development object itself; it is an immanent process with the source embedded in the object itself.

In the concept of developmental education by V. Davydov ${ }^{3}$ development is interpreted as the abilities formation by means of performing activities in various fields. The author's concept is aimed primarily at the formation of the student's personality, actualization of their personal agency, thinking skills, the ability to learn by creating situations for solving problems. The students work out the concept that contributes to their theoretical thinking development and aims to reproduce wholeness of the object, its history, its genesis and development using the convergence. Working out of the theoretical concept in particular constitutes the method of convergence, since it maps an object from its individual element to the specific developed whole. The weak point of this concept is insufficient consideration of the individual learning trajectory of each student.

L. Vygotsky ${ }^{4}$ interpreted the process of cultural development as mastering the behavior while generating personal agency and forming special personal structure consisting of internalized cultural means. According to L. Vygotsky, the source of human cultural development is concentrated in its very nature and organism that is imperfect and underdeveloped in comparison with the organism of animals. Cultural development is considered as a special process of "ingrowing" of the

3 Davydov, V. (1996) Teoriya razvivayushchego obucheniya [Theory of developing education]. Moscow, Russia: INTOR. (in Russian)

${ }^{4}$ Vygotsky, L. (1982) Sochineniya. [The collected works]. Moscow, Russia: Pedagogika. (in Russian). 
person into the culture, that implies gradual behavior mastering. Personality formation is its prerequisite that provides newly formed structures connected to the developmental age. The author considers consciousness as the "integral expression" of the highest, most essential features of the personality structure. Age transitions take place on the basis of the consciousness restructuring.

L. Vygotskyi explains that changing of social situations of development leads to the personality development and age-related transitions. The game is a cultural form of development due to the semantic field that it creates. Staying free in this semantic field becomes a priority for the person. The author determines cultural age of the person by the age of freedom as development is based on the freedom development.

Periodization of the child's development by D. Elkonin ${ }^{5}$ is build on the logic of activity vectors. First, he identifies the period of the motivation and needs development in the activity (i. e. work with the meaning). It is followed by the development of operational and technical side of the personal activity. They periodically dominate and interchage. Different chronological ages distinguish a certain type of activity with different types of mediation. In some of them person-to-person relations are mediated by subjects, in others - person-to-subject relations are mediated by people. According to D. Elkonin leading activities belong either to the first (motivational group) or to the second (operationaltechnical group) types of activities. The leading type of activity determining age periodization is typical for each age. Thus, development depends mainly on activity but not personality itself.

V. Slobodchikov ${ }^{6}$ interprets the personal development as the development of person's natural abilities. Considering this process as the history of the human subjectivity evolution, he offers a map of

${ }^{5}$ Elkonin, D. (1994) Vvedenie v psikhologiyu razvitiya [Introduction to the developmentl psychology]. Moscow, Russia: Trivola. (in Russian)

${ }^{6}$ Slobodchikov, V. (1991) Kategoriya vozrasta $v$ psikhologii i pedagogike razvitiya. [Category of age in psychology and pedagogy of development]. Voprosy psikhologii, no. 2. pp. 37-49. 
development for tracing the individual trajectories of the person's dynamics. As V. Slobodchikov notes, this periodization is an epigenetic combination presenting all ages simultaneously. The author's view does have sense as no end can be found to any age period in a lifetime as well as no age crisis can be fully resolved during life. In addition, the sequence of ages is not considered to be inviolable for everyone. V. Slobodchikov relies on the original "general law of living systems development"; each of them is formed and developed according to their own laws. A closed "life cycle"is formed of the stages of birth, maturation, peak and dying where each of them can distinguished.

B. Elkonin ${ }^{7}$ explains development as a simultaneous movement, retention of the original and reproduction of the initial state, illustrating the correlation of real and ideal forms. The reproduction of the initial state means the reflection of the ideal form or image based on the well-being, as the fullness of the own activity without any needs and desires to satisfy them. The object of activity here is the activity itself, the full state of well-being; it is achieved throughthe person's vertical coordination of the horizontal breaks, parts and incoherence.

All the reviewed concepts are to some extent limited by subjectrelated activity. Development is studied in the context of the subjectrelated activity and thinking components; this approach is based on the ideas of subjectivity and creativity: the person creates the world of subject-related activity and lives in it, and through this world they create themselves, their "inorganic body". Swiss biologist and philosopher J. Piaget $^{8}$ developed the theory of intellectual development from infancy to maturity. Piaget's main focus is on the development of logical thinking; thus the stages of intellectual development were determined: sensomotor, pre-operative, specific

${ }^{7}$ Elkonin, D. (1995) Psikhicheskoe razvitie v detskikh vozrastakh. [Psychic development in child age]. Moscow, Russia: Institut prakticheskoi psihologii. (in Russian)

8 Piaget, J. (1994) Izbrannye psikhologicheskie trudy [Selected works in psychology]. Moscow, Russia: Mezhdunarodnaia pedagogicheskaia academia. (in Russian) 
operations and formal operations. The theory of cognitive development is fragmentary, since intellectual potential is a component of the personal creative potential.

The theory of positive disintegration by K. Dambrowski ${ }^{9}$ is of big heuristic value for the study of personality development; its basic idea is that the person is capable of continuous development, and even is bound to develop. The process of continuous personality development involves biological phases and socio-psychological levels and goes on due to the individual's system of internal tendencies and dynamics (single or multilevel, hierarchical or equivalent, harmonious or contradictory).

Development potential is a resource of constant movement and change of the personality under the influence of the hierarchy of intrinsic values and motivation. The author identifiesits features such as sensitivity, interests, abilities, etc.

The explication of the development process through the mechanisms of positive disintegration is worth analyzing. Disintegration is explained as the open long-life process that has no principal completion. Positive disintegration is found in weakening, breaking of the original integrity and coherence because of destroyed links between the structure elements or the original structure breakdown. The process of positive disintegration takes place in ontogeny, in neuroses, psychoneuroses, in external (social, interpersonal) and internal conflicts. Positive disintegration is the process that ensures the dynamics of personal creative growth. Its important starting point is the "positive maladaptation" of the person to reality. In such maladaptation the author sees signs of a unique creative character of the personality which reflects its independence development. K. Dambrowski considers increased mental excitability, internal conflicts and crises, fears, depressions, etc., as indicators of dissatisfaction with stable reality and actualization of the need to search for another reality, different from the daily monotonous and

${ }^{9}$ Dambrowski, K. (1977) Multilevelness and Positive Disintegration. New York : Dabor science. 
boring one. This way the need to overcome phase connections is realized: the personovercomes this biological cycleby their choice. The author is convinced that the person has no other way but to potentially developthrough thishard work.

Going beyond the biological phases of development implies the evolution of self-reflection andemergence of internal conflicts.It is the basis for person's defence mechanisms awareness and emotional maturation that leads to the increase of empathy, internal independence, the need of personal interaction, etc. The development of personal consciousness does not depend on the biological phases and is mainly connected with overcoming their own mental type, i.e going beyond stability. Conscious internal restructuring, selfeducation, and self-psychotherapy play a leading role in the transition from subordination to automatisms (meaning self-regulation based on defence mechanisms) to the organization of individual program of internal changes including hierarchy of needs, values and goals.

The phenomenon "positive maladaptation" in K. Dambrowski's theory indicate organizational processes of the individual creative potentialaccompanied by maladaptation, inadequate behavior due to de-actualization of standard defence mechanisms. Further development of the individual is not determined by psychobiological factors only as a conscious transition to the "human" path of development takes place. It is presented as a 5-level cycle:

$1^{\text {st }}$ - primary integration;

$2^{\text {nd }}-$ one-level disintegration;

$3^{\text {rd }}$ - spontaneous multilevel disintegration, impulsive and insufficiently organized;

$4^{\text {th }}$ - systematic and multi-level organized disintegration;

$5^{\text {th }}$ - secondary integration (level of personality per se).

The first level and the starting point of further levels of development is described by the author as the primitive coherence of instincts with subordinate intelligence; unilateral intellectual development with underdeveloped feelings. According to K. Dambrowski, the first level is peculiar to most so-called ordinary people, as well as those who are on the verge of psychopathy and 
psychopathology. Aggressiveness, agility, and dynamism are typical for them. Their own interests are dominating and lead to making quick decisions using other people for achieving their own goals.

At one-level disintegration, the person is focused on the standards of the outside world, having doubts, hesitation, and uncertainty when making traditional decisions. Emotional relationships with others can be addictive. Internal conflicts are the result of a case or superficial impulses, not an internal struggle. Strong emotional conflicts, reactive states, impulsive actions lead to mental breakdowns. Due to the weakening of the primary integrative structure, in case of the absence of a formed hierarchy of values, psychoses, phobias, psychosomatic disorders, alcoholism and drug addiction are possible. Sensitivity can lead to degradation. As K. Dambrowski notes: "All this often leads to suicides and mental disorders"10.

At the level of multilevel spontaneous disintegration, extensive differentiation of psychic structures and functions is noticeable. The behavior is caused by internal processes; uncertainty is replaced by a perspective feeling of "what should be" as opposed to existing in the personality structure. This understanding is the source of the strongest impulses of development, the phase of true humanization of psychic functions. It is characterized by internal doubts, tensions, anxiety, fear, depression, etc. The author considers determining of values and the forming of their hierarchy to be the main impetus for development. Emotional connections become more selective and tend to be exclusive; internal conflicts as a reflection of the hierarchical organization of emotional life are typical. Forces that have a transformative effect (dynamisms by $\mathrm{K}$. Dambrowski) provoke astonishment and concern of the person about themselves and their surroundings, dissatisfaction with themselves, feelings of inadequacy, shame and guilt; positive maladaptation, creative tension. Usually, such reactions are considered psychoneurotic, abnormal, but

${ }^{10}$ Dambrowski, K. (1977) Multilevelness and Positive Disintegration. New York : Dabor science (p. 27). 
K. Dambrowskidescribes such mental states as the capacity for internal mental development and signs of mental health. K. Dambrowski's research and experience of clinical work prove the progressive character of most psychoneurotic processes. At the level of spontaneous disintegration, special "immersion" into person's own increased excitability, positive maladaptation, psychoneurosis of fear, depression takes place. Instead, the dynamism of development through self-observation, self-esteem, comparison with other people is actualized. Objectivation of self is inversely proportional to subjectivation towards other people, in the sense of treating them not as a means, but as the living person. At this level, internal regulation is made by the "third factor", i.e a complex dynamism derived from many factors operating at the same or at lower stages. It is a complex of mental states associated with the person's active attitude to themselves and to the environment. They gradually form autonomous and authentic factors, which fully fulfill the task of person's development and their life choice at the highest levels of mental development. The first factor represents heredity and its development potential; the second factor is the influence of the environment, social one in particular.

When the internal psychic environment is formed, the elements that gradually make up the "third factor" appear. For example, at the level of spontaneous disintegration, it is feeling of guilt and shame, self-dissatisfaction, anxiety, desire for creativity. K. Dambrowski notes that from a scientific point of view it is difficult to determine the source of the emergence and development of the "third factor". Some scientists look for it in heredity or sociality.

At the level of systematic and multilevel organized disintegration, self-control, self-education and autopsychotherapy are important. Self-control regulates development and impedes the processes that hinder it; self-education implements the systematic development program; autopsychotherapy is a kind of self-education in periods of conflict and psychoneurosis. At this level of development, empathy as compassion and love involves willingness to protect others, to help them; identification means adequate empathic 
feeling, understanding and accepting of the feelings and concerns of other, often totally different, people; a focus on self-improvement involves working on the person themselves rather than criticizing others; internal conflict reflects the contradictions in the pursuit of excellence.

The process of development at the fourth level involves the transformation of the due into the real. Secondary integration dynamisms, in particular responsibility for solving socially important tasks, are beginning to take effect; autonomy based on belief in the person's own internal progress reveals in affirmation themselves at the highest levels; empathy, responsibility, autonomy, authenticity, high level of social consciousness. In the process of multi-level restructuring of subordination, the dynamism of the lower levels is replaced by the balance and autonomy of the higher levels. The lower levels break up and become excluded from the secondary integration structure. At the same time, their disappearance makes returning to lower levels of functioning impossible.

At the stage of secondary integration, as the highest level of development, the process of progressive synthesis leads to harmonious unity, which is a function of the "most complete embodiment of the ideal". Internal conflict no longer exist because the due becomes the real. According to K. Dambrowski, integrity, harmony, high level of self-reflection, consciousness, the ability to self-choice, selfconfidence, assurance in the value of own goals, awareness of the development incompleteness and the need for constant development are the main characterictics of the personality.

At the development peak the person is guided by the "personal ideal" which is based on the permanent norms and qualities of people which were approved and realized by mankind at the dawn of its culture and are considered unconditional. They manifest themselves through the history of mankind, accumulating mainly in famous historical figures.

The resercher's viewpoint about the development incompleteness regardless of the level of ideal achievement, and professional generelized description of the factors of personality states 
dynamics at different levels of development are exceptionally important.

\section{The Ego Development Model as a Basis for Explication of the Development of the Personal Creative Potential}

The model of development as a unity of discontinuity and continuity is presented in the comparative theory of the ego development by $\mathrm{J}$. Loevinger ${ }^{11}$. Among modern theories of development, it is considered to be an adequate basis for explicating the creative potential development of the individual.

The theoretical model by J. Loevinger highlights a series of successive stages of ego development. The author does not try to attach them to the chronological age of the person, however she admits they set a clear logic of development and build a hierarchy that further reflects personal maturity. Some stages are regarded as major, others as transitional. Each stage is presented as a complex structure having features of managing impulses, interpersonal relationships and awareness of the cause of behavior. The boundaries between the stages are indistinct. If the psyche gets stuck at a certain stage, the last of the genetic characteristics becomes individually-typological.

The researcher starts studying the ego development from the pre-social stage, when the gradual separation of baby's ego out of the outside world happens. In this process, reality as a stable space of external objects is constructed along with ego that exists independently of them. "The child who stays at a stage where ego is not separated from the world of inanimate objects longer than it should be is called autistic" ${ }^{\prime 2}$. The creative potential at this stage is focused on the unconscious level of the psyche. Consequently, autism at this stage is the evidence of the dominance of creative potential. Self-regulation process preserves the stability of its initial state, primary unity.

11 Loevinger, J. (1976) Ego development: conceptions andt heories. SanFrancisco: Jossey Bass Publishers.

12 Loevinger, J. (1976) Ego development: conceptions and theories. SanFrancisco: Jossey Bass Publishers (p. 15). 
At the symbiotic stage, the separation of the ego continues. Symbiotic relationship of the child with the mother or replacing her person is crucial in this period. This process is greatly facilitated by language; in particular estranged and neglect vocabulary disrupts the stability of the symbiotic relationship. Thus, the word "no" which is the key and most commonly used tool in symbiotic disintegration with further actualization of the activity limits moving to the next stage.

For impulse stage, the child's creative potential is manifested in impulsive activity and in typical individual-age sexual acts. However, J. Loevinger points out that cognitive preconditions appear for the development of causal relationships. Fixation at this stage determine the unmanageability and inadequacy of the child's actions. Such features, presumably, are caused by disintegrative dynamics and inconsistency of processes of self-regulation and self-organization. The increasing activity of the self-organization process gives a feeling of self-power and the ability to embody it in spontaneous activity; it is followed by the feeling of primitive satisfaction based on ventilation. The lack of proper regulation results in the destructive nature of the child's actions.

The child asserts their own identity on the basis of a sense of potential individual strength. Their actions are of non-standard, original, unique and perform the catharsis function. Analyzing the content of the ego development at the impulsive stage, J. Loevinger notes that to make the transition to the higher level, the child must understand, "that each thing has causes or reasons, that impulse is not the same as action, so it is possible to postpone the action and control it at least for a short time ${ }^{13}$.

The next transitional stage is a self-defense stage. The child receives their first social and psychological experience when important adults react to their behavior. External regulation of the child's individual activity increases the internal tension and actualizes the process of creative potential self-regulation. Peculiarities of ego and

13 Loevinger, J. (1976). Ego development: conceptions and theories. SanFrancisco: Jossey Bass Publishers (p. 178). 
creative potential self-regulation in this period are connected with psychological defense mechanisms actualization. The term "defense mechanisms" was used by S. Freud to define all mechanisms that weaken the dialectically unified internal-external conflict and regulate individual behavior.

A. Freud ${ }^{14}$ considered the defense mechanisms as a product of age development, unconscious ways of reaching a compromise between opposing forces of Id and the Superego and external reality. The first child's psychological defense is connected with the negative experience of their spontaneous self-expression. Inability to respond arbitrarily causes psychological tension, generating anxiety and destabilization of the Ego image. Under the influence of defense mechanisms destructive impulses are blocked or transformed. Psychological defenses are appropriate when forms of communication and conflict with the environment are limited by the level of personal development. They promote automatic adaptation to the environment through self-protection. Every child's defense mechanism is initially formed to cope with specific instinctual desires. Thus it is related to a particular phase of individual development.

E. Romanova ${ }^{15}$ explains defense mechanisms as primary intrapsychic formations that are caused by the restriction of the child'sspontaneous expression. In the early stages of ontogeny, adults are particularly intense in limiting the expression of the child's desires, thoughts and feelings. It leads to external conflict which is further internalized. Defense mechanisms are indirect ways of experiencing and coping with emotional conflict.

Gradually, the child begins to anticipate encouragement and punishment in the immediate future but the child is not able to adequately control their own behavior yet; and the need for defense

${ }^{14}$ Freud, A. (1993) Psikhologiya «Ya»i zashchitnye mekhanizmy [The Ego and the mechanisms of defense]. Moscow, Russia: Prosveshchenie. (in Russian)

15 Romanova, E. (1996) Mekhanizmy psikhologicheskoy zashchity: genezis, funktsionirovanie, diagnostika [Mechanisms of psychological defense: genesis, functioning, diagnostics]. Retrieved from http://www.syntone-ufa.ru/library/books. (accessed 10 October 2019). 
activity is caused by excessive sensitivity. At this stage, the child is made aware of the rules and values and the principle of reality isintroduced into their life. The main value for the child is achieving comfort and avoiding discomfort. Using the rules for own benefit is a more progressive act than the need to contain impulses through external constraints. There is no holistic attitude to self at this stage; there is a sense of guilt integrated with discomfort, but its causes are projected on external objects or on the alienated part of self. Consequently, getting stuck at this stage causes hyperfunctions of the defense mechanisms, the desire to get maximum satisfaction at the expense of others with minimal stress.

Thus, the early pre-conventional stage remains a layer of primary experience in the subconscious and determines the starting positions of further non-linear dynamics of creative potential development. Fixation at the defense stage determines the perception of the world only in terms of person's own selfish needs and desires. The only way to get the desired is to control the environment and protect yourself. At the same time, it is important to understand that the creative opportunities potential in this case is aimed to getting the desired, which accompanies the sensory developmentand promptness of goals realization.

Signs of further development of the Ego in the conformism stage are revealed when the child begins to harmonize and relate their own comfort with the comfort of the outer space. The individual level of trust is an important prerequisite for this condition. In the case of being stuck on a destructive variant of the self-defense development stage, aggression, exploitation, deception, manipulation become typical for the person. The conformist follows the rules not because of fear of punishment, but to get approval from the targeting reference group, while group disapproval becomes a serious punishment. Group membership is a guarantee of safety. The regulation of creative potential is extrapolated and determined by an external force - an authoritative person or group of persons.

The stage of self-awareness is transitional from conformism to consciencestage according to $\mathrm{J}$. Loevinger. The development of 
awareness of the realEgothat is not quite in line with the ideal image or rules takes place. The content of the inner life at this and the previousstagescan be described by common stereotypical formulations. Self-awareness is a prerequisite for the further replacement of group standards and criteria by personal ones. In addition, if a conformist lives in a conceptually simple world where the word "no" means the same thing to everyone, at the level of selfawareness the person sees possible alternatives and exceptions to the rules, albeit so far in a stereotyped and generalized form. Also awareness of individual differences in character traits begins to emerge.

At the conscience stage, a radical complication of the mechanisms of self-regulation takes place. Few 13-14-year-olds are able to reach this stage. At this time the internalization of the rules iscompleted and there are basic elements of conscience: "long-term goals and ideals, differentiated self-criticism and a sense of responsibility"16. At this stage, the regulation of the personal creative potential is determined neither by the fear of punishment nor by a sense of conformism, but by a sense of responsibility as a guideline of individual behavior. The person who has reached this stage is not apt to feel guilty about breaking rules, but feels discomfort when doing harm to another person, even within the existing rules. A sense of responsibility for the own life and others develops; the concepts of obligations, privileges, rights and justice is formed. There is a desire for achievement on the basis of personal standards and criteria, acceptance of the importance of work, distinction between morality, traditions and fashion; the dichotomy of "right - wrong" and "good bad" is replaced by more complex and differentiated constructs. Main features of inner life at this stage are a variety and complexity of emotions, a shift of attention from the actions to their depthcauses, the ability to feel in the position of another person, expansion of temporal perspective and social contexts for understanding phenomena, events

16 Loevinger, J. (1976). Ego development: conceptions and theories. SanFrancisco: Jossey Bass Publishers (p. 20). 
and actions. Presumably, the conscience stage determines the positions for the internal regulation of creative potential.

At the individualistic stage, awareness of the identity feeling and problems of emotional interdependence of people appears replacing the moralism. Depth emotional reasons and problems of interpersonal relationships, and partly internal conflicts are considered. "Developed ability to accept paradoxes and contradictions leads to greater conceptual complexity, which is expressed in the awareness of the differences between the inner essence and external manifestations, between psychological and physiological reactions, between the process and the result", 17 .

At the autonomy stage the person has the ability to accept and manage internal conflict (between needs, obligations and both). "Perhaps autonomous personality has not more conflicts than others, but they have hardiness and other necessary qualities to accept a conflict and work with it instead of ignoring or projecting it to the outside world"18. The autonomous personality is capable of overcoming polar oppositions and perceiving the world in its volume and diversity. Conceptual complexity, high tolerance for uncertainty and making own mistakes are features of the autonomous personality. The autonomous personality respectsother people's need for autonomy, is free from the "dictatorship of conscience" in contrast to the previous stage, but is aware of the autonomy limitations and dialectic as well as emotional interdependence. A broad worldview, realism, objectivity, commitment to abstract ideals are typical for autonomous personality.

The last is the integration stage, which is the most difficult to describe because it rarely happens; it is distinguished from the autonomous stage by the consolidation of the identity sense. J. Loevinger compares this state with the well-known description of self-actualized

17 Loevinger, J. (1976) Ego development: conceptions and theories. SanFrancisco: Jossey Bass Publishers (p. 22-23).

18 Loevinger, J. (1976) Ego development: conceptions and theories. SanFrancisco: Jossey Bass Publishers (p. 23). 
personalities according to A. Maslow ${ }^{19}$. Leading expert in adult psychology and the theory of ego development S. Cook-Greuter ${ }^{20}$ studies the dynamics of different ways of making sense of reality or partial situations at the conventional and post-conventional stages.

The empirically sustainable description of the possible variant of creative potential development by J. Loevinger is heuristically valuable. It comprises stages from unconscious, undifferentiated symbiosis of the infant to the mature adult's conscious experience of commitment to the universe. The author goes in her studies from prerational to metarational, from pre-verbal phase to original postsymbolic wisdom when the person becomes aware of natural relations of all phenomena and the artificiality of borders, objects, traditional self-identification and becomes free. It is important that the researcher considers development through a dichotomy of stages determined by differentiation and integration; separation and participation; governance and connectedness; independence and unification; care and justice.

She points out that at conformist, conscience, autonomous, and integration stages of development the personality is balanced due to dominating integration and harmonious relationships with their newlyfound community that correspond to individual cognitive, emotional and cognitive needs. For the self-defense, self-awareness, individualistic stages, according to S. Cook-Greuter, differentiation and increased levels of tension, anxiety, uncertainty are typical. Consequently, these indicators testify to periods of self-organization and creative potential realization through a transgressive transition beyond the achieved stability.

The personality developments tages are of great heuristic value for this research as in its context they are related to the development of

19 Maslow, A. (1997) Dal'nie predely chelovecheskoy psikhiki [The Farther Reaches of Human Nature]. St. Petersburg, Russia: Eurasia. (in Russian)

20 Cook-Greuter, S. (2005) Ego development: Nine levels of increasing embrace. Retrieved from http://newpossibilitiesassociates.com/uploads/9_levels_ of_increasing_embrace_update_1_07.pdf (accessed 15 October 2019). 
creative potential on the basis of productive internal regulation of personal dignity, realization freedom and conscious responsibility. At the conformism stage, according to S. Cook-Greuter, a linear worldview is a distinctive personal feature: objects are defined within specific limits, causality seems linear, and variables are independent. The person's mindset and priorities depend on the values, priorities, and status of the group to which the person belongs. The boundaries between Ego and others are tangled and blurred. On this basis, creativity development is studied in the process of adaptation as the basic need of the conformist stage is to be accepted.

At the self-awareness level, the creative potential is governed by high moral standards and conservative orientations for correctness in the fulfillment of their duties, and is manifested in compulsive behavior and perfectionism. It is connected with the power of the super-ego and exceedingly critical attitude to other people's thoughts, as pointed out by S. Cook-Greuter. Therefore, this is the level of dominating self-regulation and stability retention; that is why information that does not fit into standard schemes is denounced, rejected or discredited. Although complex decisions, better ideas, more sophisticated procedures are possible at the self-awareness stage, linear thinking prevents the person from identifying priorities of various opportunities and synthesizing them. Self-regulation of creative potential defines protection, ultra-rationality that involves imposing the own understanding of values on others and forming a pragmatic style of domination. The creative potential in the form of rational competent activity enables democratic interaction.

At the level of conscience, the creative potential of the individual is realized in the ability to go in with other people being loyal to their values. Cognition through feedback and introspection allows to understand own self, develops capability of selfimprovement. Formal operations and abstract rationality are used to find out the nature of things, including human nature. The conscience level of creative potential development is manifested in the willingness to realize the idea of "goodness for all". The personality is aware of the potential evolution process, based on the analysis of self and 
others, self-knowledge and continuous improvement. Guilt is one of the main emotions, extremely strong self-criticism. Creativity development is affected by excessive critical, neurotic selfpunishment. Conscientiousness is manifested in the self-regulation of life, in particular responsibility, honesty, rational decisions and acts to improve the world. Rationality, progressivism, positivism and reductionism are distinctive features of creativity.

Analyzing the individualistic level of the postconventional stage, S. Cook-Greuter notes that the perception of reality is characterized by a systematic nature that allows the individual to acquire a more holistic state involving feelings and contexts of the life activity process. The reassessment of previously uncritically perceived things takes place, including role-identified identities and selfredefining. It happens because the priority of a unique creative potential, independent of society and focused on cognition of the inner world and its special meanings, is recognized. Distancing from the world to acquire own identity, the person often brings creativity into the activity, a new vision of particular problems, or inspires others with their enthusiasm to follow their interests. Linear, intellectual logic gives way to a holistic understanding of phenomena and processes. It becomes possible due to trust - a quality that opens the personality for development. Convincing, justifications, analysis are inferior in value to subjective experience.

Personality concentrates their own creative potential on processes, relationships and non-linear influences of different variables. The existential sense of difference and peculiarity of every moment of being is obvious. Intrinsic contradictions caused by processes of differentiation, actualizing the conscious desire to integrate different parts of creative potential,are typical. At the same time, the creative orientation of the person to the cognition of their feelings and motivation develops an awareness of the imperfection or limitations of self-regulatory processes along with the use of defense mechanisms. As it was stated above, they are considered to be self-deception and distort social and perceptual experience. On the other hand, the ability to reflection increases. The creative potential at the individualistic stage is 
characterized by energetic self-expression and carelessness, spontaneity and ability to live according to their own unique features, free from the limitations of society. However, unpredictability and freedom sometimes makes interaction with others difficult.

In the autonomy stage, personal creative potential acquires the ability to integrate its parts. Own interpretation of the experience gets more meaning. At the autonomous stage, the creative potential of the individual is realized consciously, life activity is meaningfulness due to the self-determination and self-actualization in the dynamic context. At this stage, the person is able to consciously reconcile their internal development processes. Due to the awareness of the shadow aspects of the personal creative potential, a qualitatively new stage of integration becomes available. Responsibility regulates conflicting needs, experience is perceivedwith immediacy, creative potential is not used fordefense, those are indicators of tolerance and spontaneity.

The personality needs the presence of others to fully realize their creative potential: dynamic and close exchange with others leads to deep self-cognition and reaching the wisdom. Interaction with others is essential,it is experienced with awe and awareness of responsibility for them. At the autonomy stage, the regulation of personality functions through conscious defenses: altruism, humor and forethought. Creative potential is focused on providing selfactualization and self-realization.

At the second level of the post-conventional stage, S. CookGreuter distinguishes two periods on the basis of newly formed structures and understanding of different layers of symbolic abstractions: construct-conscious and integrated. The researcher notes that ability to make fundamental assumptions about human nature and the need to create order out of chaos are existential problems of personality. So, creativity involves awareness of the development model, visibility of the own development thatcomprises wide range of experience and thoughts. The personality is aware of the used intellectual defense tendencies for self-preservation.

In the construct-conscious period, creative potential is directed to a dynamic and diverse understanding of human nature, difficulties 
of human interaction and can be realized through the need to create theories and concepts. Processes of self-awareness and reasoning become more differentiated; access to intuition, bodily states, feelings, dreams, archaic and transpersonal experiences widens. The ability to acquire knowledge from irrational sources of information is increasing in the post-conventional development period.

It is important that the regular practising of focusing on the own inner world and observing mental processes often leads to spontaneous manifestation of ways of being when knowledge and cognition are instantly merged, and the feeling of Ego dissolves. A. Maslow ${ }^{21}$ defines such states of higher creative experience of grace as peak experiences.Creative potential is free from constant Ego control. In the construct-conscious period, the person experiences changes and evolution due to the sensitivity and ability to understand others in terms of development.

The integration stage of development is determined by a completely different way of perceiving human existence and consciousness. S. Cook-Greuter notes that the new paradigm has a universal or cosmic perspective. The personality considers themselves and others as a part of humanity, originating from the creative foundation with an evolutionary purpose. The two poles of the Pascal paradox integrate: the person experiences the belonging sense and the sense of isolation and uniqueness without tension as a change in the perception of the opportunities variety of being. Birth, growth and death, joy and pain are understandable natural events, change modes in the life flow. Conscious or rational awareness is no longer perceived as a limitation, but as one of the dominating phenomena that depends on the present moment. Internalized transpersonal or interpersonal morality is a feature of the integration period. Internal conflicts and conflicting external needs are parts of being that require not solution but testifying. Spontaneity, independence and impersonal attitude allow the person to act directly and powerfully in case of need. Reality

${ }^{21}$ Maslow, A. (1997) Dal'nie predely chelovecheskoy psikhiki [The Farther Reaches of Human Nature]. St. Petersburg, Russia: Eurasia. (inRussian) 
can provoke deep emotional experiences as an undifferentiated phenomenological continuum or as a creative basis for integrated consciousness.

The sense of interconnection with all living beings in their struggle for survival and for recognizing the sense of their existence dominates at the integration stage. Typical features of the personality are tolerance, compassion and connection with life. Absolute openness makes it possible to set the person up for the truth, kindness and beauty, visionary experiences, understanding wholeness of things. High level of trust to the worldallows to process information and experience without conscious willful attention to it. Creativity is realized for everybody's benefit and on the basis of responsibility for sense creating. Activity and thinking are just in existence modes; they are not more valuable than feelings, existence or non-existence.

The integration stage of creative potential development is expressed in a balanced, integrated sense of independence, in particular separation. The person feels as a part of the constant universe evolution in all aspects of the cycle of creation, destruction and re-creation.

The meaning of development is not in the desire and ability to reach quantitative and qualitative increase or decrease of meaningful indicators, but in the formation of new fundamental backgrounds of the structure where the relationships between its elements are reestablished.

The theory of Ego development allows to understand the ontogeny of creative potential from the level of localization of the creative resource in the unconscious layers at the stage of symbiotic unity to the higher level of its integration with the world at the postconventional stage.

\section{CONCLUSIONS}

The research is based on modern scientific and philosophical positions and interprets development as a special kind of internal change which is associated not only with the emergence of new elements, but with changes in the structure and relationships between its elements. In 
most theories, human development is presented as a spiral movement, possible in all directions. The creative potential goes upward under the influence of spiritual values due to the need for self-actualization and personal dignity. "Vertical" development implies progressive transformations in the structure of the personal creative potential, person's life activity and environment. Horizontal movement and change are explained as expansion, movement within the same stage (development of skills, accumulation of knowledge). The creative potential provides adaptation to the conditions of the actual space and the use of its resources for life support. Downward movement causes temporary or permanent regression, mostly caused by fixation on the unsatisfied need at previous development stages. In most cases the creative potential of adults is represented in horizontal extension. People acquire new skills, techniques, ways of organizing knowledge, but the stage of their personal development, mental world model, dignity status, level of development and realization of creative potential remain unchanged.

In this research personal creative potential is interpreted as the process of transition immense potentiality into reality, accompanied by transgression and movement to a higher stage. To explicate personal creative potentialdevelopment the model of comparative theory of ego development by J. Loevinger was integrated with the concept of Ego development stages by S. Cook-Greuter. The study was focused on the revealing possibilities of internal regulation of the personal creative potential by the conscious responsibility level. Thus, the responsibility dynamics was traced at the conventional stage starting from its diffuse form at the conformismlevel, critical intensification to the sense of guilt at the conscience level, and gradual improvement at the postconventional stage due to the trust to the self and to the world.

\section{SUMMARY}

The issue of personal creative potential development is studied. In the anthropocentric paradigm, the current status of the "creative potential"phenomenon is relevant. The latent character and nonlinear determination of its development stipulates the nesessity for scientific and psychological analysis of the Ego development in ontogeny. 
Development is considered as a special kind of internal change related to the emergence of new elements, as well as changes in the structure and specificity of the relationships between the elements.

The development of the creative potential of the individual is explicated on the basis of the model of Ego development. The logic of its development is related to the content and features of the Ego development stages. Possibilities of internal regulation of the personal creative potential by the conscious responsibility level are revealed. The dynamics of responsibility is analyzed starting from its diffuse form at the conformism stage to the trust level to the self and to the worldat the post-conventional stage.

\section{REFERENCES}

1. Heidegger, M. (2003) Bytie $i$ vremya [Being and time]. Kharkov, Ukraine: Folio. (in Russian)

2. Shchedrovitskyi, H. (1995) Izbrannye Trudy [Selected works]. Moscow, Russia: Shkola kulturnoi politiki. (in Russian).

3. Davydov, V. (1996) Teoriya razvivayushchego obucheniya [Theory of developing education]. Moscow, Russia: INTOR. (in Russian)

4. Vygotsky, L. (1982) Sochineniya [The collected works]. Moscow, Russia: Pedagogika. (in Russian).

5. Elkonin, D. (1994) Vvedenie $v$ psikhologiyu razvitiya [Introduction to the developmental psychology]. Moscow, Russia: Trivola. (in Russian)

6. Slobodchikov, V. (1991) Kategoriya vozrasta v psikhologii $i$ pedagogike razvitiya. [Category of age in psychology and pedagogy of development]. Voprosy psikhologii [Psychology Issues], no. 2. Pp. 37-49.

7. Elkonin, D. (1995) Psikhicheskoe razvitie $v$ detskikh vozrastakh [Psychic development in child age]. Moscow, Russia: Institut prakticheskoi psihologii. (in Russian)

8. Piaget, J. (1994) Izbrannye psikhologicheskie trudy [Selected works in psychology]. Moscow, Russia: Mezhdunarodnaia pedagogicheskaia academia. (in Russian) 
9. Dambrowski, K. (1977) Multilevelness and Positive Disintegration. New York : Dabor science.

10. Loevinger, J. (1976) Ego development: conceptions and theories. SanFrancisco: JosseyBassPublishers.

11. Freud, A. (1993) Psikhologiya "Ya" $i$ zashchitnye mekhanizmy [The Ego and the mechanisms of defense]. Moscow, Russia: Prosveshchenie. (in Russian)

12. Romanova, E. (1996) Mekhanizmy psikhologicheskoy zashchity: genezis, funktsionirovanie, diagnostika [Mechanisms of psychological defense: genesis, functioning, diagnostics]. Retrieved from http://www.syntone-ufa.ru/library/books. (accessed 10 October 2019).

13. Maslow, A. (1997) Dal'nie predely chelovecheskoy psikhiki [The Farther Reaches of Human Nature]. St. Petersburg, Russia: Eurasia. (in Russian)

14. Cook-Greuter, S. (2005) Ego development: Nine levels of increasing embrace. Retrieved from http://newpossibilitiesassociates.com/ uploads/9_levels_of_increasing_embrace_update_1_07.pdf (accessed 15 October 2019).

15. Konovalchuk, V. I. (2016) Tvorcha osobystistj u prostori osvity [Creative personality in the education space]. Umanj : FOP Zhovtyj O. O. (in Ukrainian)

Information about the author:

Valentyna Afanasenko, Doctor of Philosophical Sciences, Candidate of Psychological Sciences (PhD), Chief of the Psychology Department, Cherkasy Regional Institute for Postgraduate Education of Teachers 38, Bydhoshchska str., Cherkasy, 18000, Ukraine ORCID ID: orcid.org /0000-0002-9219-7087 